\title{
Aktor dan Konfigurasi Subsistem dalam Perubahan Kebijakan Pengolahan Sampah Menjadi Listrik di Provinsi DKI Jakarta
}

\author{
Sri Utami Gayatri', M. Baiquni², Muhadjir Darwin ${ }^{3}$, dan Tumiran ${ }^{4}$ \\ ${ }^{1}$ Magister dan Doktor Studi Kebijakan, Fakultas Pascasarjana, Universitas Gadjah Mada, \\ Yogyakarta, ${ }^{2}$ Fakultas Geografi, Universitas Gadjah Mada, Yogyakarta, \\ ${ }^{3}$ Fakultas IImu Sosial dan IImu Politik, Universitas Gadjah Mada, Yogyakarta, \\ ${ }^{4}$ Fakultas Teknik, Universitas Gadjah Mada, Yogyakarta
}

Korespondensi: Sri Utami Gayatri (e-mail: su_gayatri@yahoo.com)

\begin{abstract}
Abstrak
Populasi penduduk di Provinsi DKI Jakarta terus tumbuh. Konsekuensi pertumbuhan populasi ini tentu saja adalah peningkatan volume sampah dan di saat yang bersamaan juga kebutuhan terhadap energi pun semakin meningkat. Pemerintah Provinsi (Pemprov) DKI sejak 2011 menerapkan waste to energy (WTE) di TPST Bantargebang, tetapi hanya sekadar unit pengolahan saja. Pengolahan sampah yang terbesar atau pengolahan sampah utama (primer) adalah landfill. Sejak 2011 juga Pemprov DKI menyusun Rencana Induk Sistem Pengelolaan Sampah (RISPS) 2012-2032 untuk menjadikan WTE sebagai proses utama atau proses di tengah dengan membuat Intermediate Treatment Facility (ITF) di empat titik di wilayah Provinsi DKI Jakarta. Pada 2018, satu ITF di Sunter mulai dibangun. Untuk mengurai permasalahan lambannya pelaksanaan RISPS tersebut, peneliti mencoba memetakan jejaring aktor yang ada serta meneropong sejauh mana konfigurasi subsistem menerima ide dan aktor baru dalam rangka percepatan pembangunan WTE. Hasil penelitian ini menunjukkan bahwa proses perubahan kebijakan berjalan secara gradual paradigmatic dengan berorientasi pada policy goals di dalam subsistem yang terbuka (open sub-system).
\end{abstract}

Kata kunci: waste to energy; sampah menjadi listrik; jejaring kebijakan; jejaring aktor; konfigurasi subsistem 


\title{
The Actors and Sub-system Configurations in Waste to Energy Policy Change - Management within the Provincial Government of DKI Jakarta
}

\begin{abstract}
Population growth in DKI Jakarta Province continues to increase. The consequence of population increase is indeed in the volume of waste which also continues to increase and at the same time the need for energy is increasing. Since 2011 DKI Provincial Government has implemented waste to energy (WTE) in Bantargebang TPST, but it was not as the main processing unit. Since 2011, DKI Provincial Government has also compiled a plan (2012-2032 Waste Management System Master Plan) to make WTE as a central processing unit by making an Intermediate Treatment Facility (ITF) at four points in DKI Jakarta Province. It was only in 2018, one ITF in Sunter began to be built. To unravel the problem of the slow implementation of RISPS, researcher tried to map the existing network of actors and to explore the extent to which the configuration of the subsystem accepted new ideas and actors in the context of accelerating WTE development. The results of this study indicated that the policy change process runs gradually paradigmatically oriented to policy goals in an open subsystem.
\end{abstract}

Keywords: waste to energy; waste into electricity; policy network; actors

\section{Pendahuluan}

\section{Latar Belakang Permasalahan}

Pertumbuhan penduduk Indonesia setiap tahun terus mengalami peningkatan. Menurut Statistik Indonesia 2016 (BPS, 2016), penduduk Indonesia berdasarkan Sensus Penduduk 2010 (SP2010) pada Mei 2010 mencapai 237.641 juta jiwa. Dalam rentang tujuh tahun (dari 2010 hingga 2017) terjadi lonjakan yang cukup signifikan, yaitu adanya penambahan sekitar 24 juta jiwa lebih. BPS mencatat bahwa jumlah penduduk Indonesia pada 2017 mencapai 261,890 juta jiwa (BPS, 2017). Sementara itu, rerata laju pertumbuhan penduduk Indonesia per tahun berada di kisaran 1,3 persen atau antara tiga sampai empat juta per tahun.

Pertumbuhan penduduk tentu tidak dapat dilepaskan dari pembangunan ekonomi, produksi dan pemenuhan kebutuhan hidup, peningkatankualitashidup, sertakesejahteraan hidup. Dalam rangka pemenuhan kebutuhan dan peningkatan kualitas hidup, pertumbuhan ekonomi harus terus dipacu. Untuk mencapai target pertumbuhan ekonomi, salah satu upaya yang dilakukan sebuah negara adalah dengan melakukan pemerataan pembangunan, baik berupa sarana prasarana atau infrastruktur maupun pembangunan sumber daya manusia. Dalam semua upaya itu, baik dari sisi pertumbuhan ekonomi, pemerataan pembangunan, atau hanya sekadar pemenuhan kebutuhan hidup, dibutuhkan kecukupan sumber energi sebagai penggerak aktivitas dan produktivitas masyarakat dan industri. Seiring dengan pertumbuhan penduduk, peningkatan pemenuhan kebutuhan hidup masyakat, target pertumbuhan ekonomi, dan kebutuhan terhadap energi juga semakin meningkat.

Di beberapa negara, pengelolaan sampah menjadi energi listrik atau yang dikenal dengan waste to energy (WTE) menjadi solusi dua permasalahan sekaligus: kebutuhan energi listrik dan terkelolanya sampah dengan baik atau sampah bukan menjadi beban (cost) 
bagi pemerintah. WTE telah diterapkan di beberapa negara, terutama negaranegara maju. Penerapan WTE dominan di kawasan Eropa, Amerika, Jepang, dan Korea. Sementara itu, di Asia Tenggara baru Singapura yang menerapkannya.

Sebenarnya sejak 2011 Provinsi DKI Jakarta telah menerapkan WTE di TPST Bantargebang, tetapi hanya merupakan bagian kecil dari proses pengolahan sampah yang ada. Dari sisi daya yang dihasilkan pun, besarannya relatif kecil karena dari kapasitas produksi sebesar 16 megawatt (MW) hanya mampu menghasilkan sebesar 3 sampai $6 \mathrm{MW}$ per hari. Pada Mei 2018, Pemprov DKI mulai membangun WTE sebagai pengolahan di proses utama dengan membangun Intermediate Treatment Facility (ITF) di Sunter. Perubahan atau inovasi kebijakan dengan pembangunan ITF ini bekerja sama dengan PT Jakarta Propertindo (Jakpro). ITF Sunter ditargetkan selesai pada 2021. Bertempat di lahan Dinas KLH Pemda DKI seluas 3 hektar, proyek senilai US\$250 juta itu dapat memproses 2.200 ton sampah per hari dan menghasilkan tenaga listrik 35 megawatt. (Kompas, 2018).

Jika melihat dokumen perencanaan yang disusun pada 2011 yang berupa Rencana Induk Sistem Pengelolaan Sampah (RISPS) 2012-2032, proyek pembangunan yang baru direalisasikan pada 2018 ini berjalan cukup lambat. Upaya percepatan sebenarnya pernah dilakukan pemerintah pusat dengan menerbitkan Perpres Nomor 18 Tahun 2016 tentang percepatan pembangunan Pembangkit Listrik Berbasis Sampah (PLTSa). Namun, perpres ini digugat oleh aktivis lingkungan karena perpres yang merujuk pada penggunakan teknologi insenerator ini dinilai tidak ramah lingkungan dan bertentangan beberapa perundangan sebelumnya. Pada 2 November 2016, Mahkamah Agung mengabulkan gugatan tersebut dan membatalkan perpres tersebut. MA menilai perpres tersebut bertentangan dengan peraturan yang lebih tinggi, yaitu UU No. 32 Tahun 2009 tentang Perlindungan dan Pengelolaan Lingkungan Hidup, UU No. 36 Tahun 2009 tentang Kesehatan, dan UU No.12 Tahun 2011 tentang Pembentukan Peraturan Perundang-Undangan (MA, 2016: 33).

Pada 2018, pemerintah kembali menerbitkan perpres untuk percepatan pembangunan WTE atau PLTsa di beberapa kota di Indonesia. Perpres Nomor 35 Tahun 2018 tentang Percepatan Pembangunan Instalasi Pengolah Sampah Menjadi Energi Listrik Berbasis Teknologi Ramah Lingkungan resmi diundangkan pada 16 April 2018. Perpres ini menjelaskan beberapa daerah yang menjadi tujuan percepatan pembanguan PLTSa, yaitu Provinsi DKI Jakarta, Kota Tangerang, Kota Tangerang Selatan, Kota Bekasi, Kota Bandung, Kota Semarang, Kota Surakarta, Kota Surabaya, Kota Makassar, Kota Denpasar, Kota Palembang, dan Kota Manado.

Pembatalan perpres yang pertama(Perpres Nomor 18 Tahun 2016) akibat gugatan aktivis lingkungan menunjukkan bahwa pendekatan regulasi tanpa didukung dengan pendekatan jejaring kebijakan para aktor menjadikan kebijakan itu tidak efektif. Aktivis lingkungan, meskipun memiliki sedikit kewenangan dalam jejaring kebijakan, dapat membatalkan kebijakan pemerintah yang memiliki kewenangan besar. Selanjutnya penerbitan perpres yang kedua semakin meneguhkan bahwa pemerintah pusat benar-benar hanya menggunakan pendekatan regulasi. Perpres No. 35 Tahun 2018 pun diprotes oleh aktivis lingkungan yang diwakili oleh Wahana Lingkungan Hidup (Walhi) dengan menyebut bahwa Perpres No. 35 Tahun 2018 tentang PLTSa merupakan pemaksaan teknologi mahal dan tidak berkelanjutan (Siaran Pers Walhi, 31 Mei 2018). 
Adanya protes dari aktivis lingkungan itu tidak menyurutkan sambutan baik dari Pemprov DKI Jakarta sebagai bagian dari pemerintah dan sebagai kota yang masuk dalam perpres itu. Namun, kehadiran perpres itu tidak serta-merta menjamin keberlangsungan dan percepatan WTE di Provinsi DKI Jakarta. Banyak faktor lain yang hadir dari jejaring kebijakan atau jejaring aktor yang perlu diselesaikan, terutama karena belief system dalam konfigurasi kebijakan antarpara aktor belum padu dan sinkron. Untuk mengurai permasalahan ini, peneliti menggunakan analisis jejaring aktor dan melihat sejauh konfigurasi subsistem merespons dinamisasi aktor dan ide. Dengan terurainya jejaring aktor tersebut, diharapkan kebijakan yang diambil pemerintah dapat lebih komprehensif untuk mewadahi aspirasi para aktor secara maksimal.

\section{Tujuan dan Manfaat Penelitian}

Penelitian ini bertujuan untuk mengurai dan memetakan para aktor yang terlibat dalam perubahan kebijakan pengelolaan sampah menjadi energi listrik. Setelah para aktor terpetakan, pada tahap selanjutnya akan dapat diukur sejauh mana konfigurasi subsistem yang terbentuk sehingga mampu mendinamisasi perubahan. Di samping itu, penelitian ini diharapkan memberikan manfaat bagi para aktor, terutama penentu kebijakan, untuk memobilisasi para aktor dan elemen lain yang berpotensi menjadi aktor agar terlibat dalam proses inovasi kebijakan.

\section{Tinjauan Pustaka}

Dalam dokumen "Indonesia Climate Change Sectoral Roadmap" (ICCSR) 2010, Bappenas menjelaskan bahwa mayoritas daerah belum memiliki master plan/action plan atau rencana aksi yang komprehensif terkait dengan pengelolaan sampah, terutama WTE. Tidak adanya rencana aksi ini tentu saja membuat daerah tidak mempunyai rencana pengelolaan sampah di dalam Rencana Pembangunan Jangka Menengah Daerah (RPJMD). Tanpa adanya master plan pengolahan sampah dalam RPJMD, tidak akan ada rencana aksi di Renstra (rencana strategis) yang dibuat oleh Satuan Kerja Perangkat Daerah (SKPD). Tanpa itu semua tidak ada perencanaan anggaran dan pembangunan infrastruktur untuk pengolahan sampah, terlebih infrastrukturyang terintegratif dengan sistem WTE.

Pada titik inilah daerah harus berani membuat inovasi kebijakan dalam menyusun master plan. Daerah harus lebih dinamis dalam menyusun RPJMD dan bukan hanya sekadar menyalin (copy-paste) dari program tahun-tahun sebelumnya. Tentu saja inovasi kebijakan ini perlu diimbangi dengan pengetahuan tentang perkembangan dan inovasi teknologi, khususnya teknologi WTE yang aman dan sesuai dengan kondisi daerahnya masing-masing. Tidak hanya di daerah, master plan juga sangat penting dibuat di skala nasional agar sinkronisasi dan integrasi program antara pemerintah pusat dan daerah terjalin. Kondisi ini menggambarkan bahwa kebijakan pemerintah dalam WTE belum menjadi agenda yang terformulasikan dalam kebijakan, yang di dalamnya terdapat inovasi-inovasi kebijakan.

Pengelolaan sampah yang dilakukan pemerintah umumnya masih menggunakan pendekatan end of pipe solution (Aditya, 2008). Pendekatan ini menitikberatkan pada pengelolaan sampah ketika sampah tersebut telah dihasilkan, yaitu berupa kegiatan pengumpulan, pengangkutan, dan pembuangan sampah ke TempatPembuangan Akhir (TPA) sampah. Seyogianya pengelolaan 


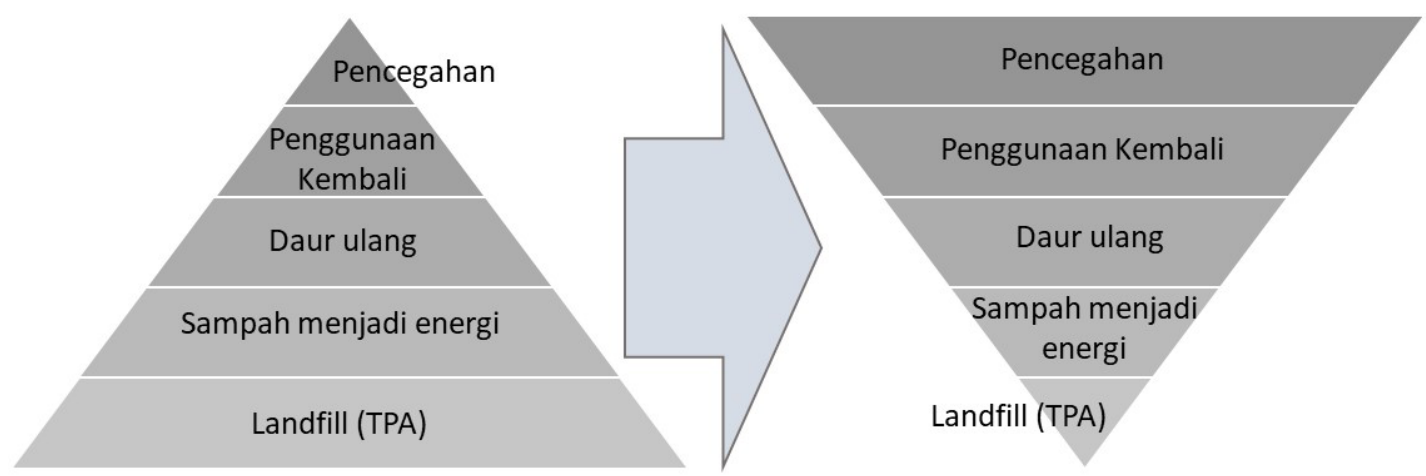

Konvensional

Trend Masa Depan

Sumber: UNEP (2010) \& ADB (2002), diolah.

Bagan 1 Piramida Pengelolaan Sampah

sampah perlu dirumuskan dan dirancang ke dalam suatu sistem dan mekanisme dalam bentuk peraturan/kebijakan pengelolaan sampah (Dedi, 2010). Dalam Bagan 1 di bawah ini posisi Indonesia masih berada di Piramida Konvensional, bahkan pengelolaan sampah di Indonesia masih bertumpu pada metode sanitary landfill atau Tempat Pembuangan Akhir.

Selanjutnya Pemprov DKI Jakarta melakukan perubahan kebijakan mengikuti tren piramida terbalik di atas. Namun, percepatan pembangunan WTE tidak sebanding dengan volume sampah yang ada dan kebutuhan energi yang terus meningkat. Oleh karena itu, kajian jejaring kebijakan diperlukan untuk menganalisis permasalahan percepatan WTE di Jakarta. Kenis dan Schneider (1991: 41) mengungkapkan bahwa jejaring kebijakan itu digambarkan oleh para aktor, hubungan antaraktor, dan batasan kewenangan antaraktor di dalam jejaring tersebut.

Menurut Howlett dan Ramesh (1995: 5059), beberapa aktor atau organisasi yang berpengaruh dalam proses pembuatan kebijakan, antara lain, adalah (a) eksekutif dan legislatif yang dihasilkan melalui pemilihan umum (elected officials); (b) pejabat atau birokrat yang diangkat (appointed officials); (c) kelompok kepentingan (interest group); (d) organisasi peneliti; dan (e) media massa. Selain lima aktor tersebut, aspek lain yang berpengaruh dalam kebijakan publik, antara lain, adalah (a) bentuk organisasi negara; (b) struktur birokrasi; (c) organisasi kemasyarakatan; dan (d) kelompok bisnis.

Sementara itu, Moore (1995:112) secara umum menyebut ada tiga aktor utama yang terlibat dalam perumusan kebijakan publik, yaitu aktor publik, aktor privat, dan aktor masyarakat (civil society). Ketiga aktor ini sangat berperan dalam sebuah proses penyusunan kebijakan. Lidblom (1980) dalam Shull (1999) menyebutkan secara garis besar, ada dua aktor dalam perumusan kebijakan publik, yakni mereka yang berada di dalam pemerintahan (Inside Government Actors/ IGA) dan yang berada di luar pemerintahan (Outside Government Actors/OGA).

\section{Metodologi}

Penelitian ini menggunakan metode triangulasi. Denzin (dalam Moloeng, 2004) membedakan empat macam triangulasi, yakni data, metode, peneliti, dan teori. Pada penelitian ini, dari keempat macam triangulasi tersebut, 
peneliti menggunakan teknik triangulasi data, metode, dan teori. Berikut adalah penjelasan dari tiap tipe triangulasi tersebut.

1) Tringulasi Data. Dengan metode ini peneliti menggabungkan berbagai jenis data berupa hasil observasi, wawancara, undang-undang, pemberitaan media, dan literatur menjadi satu kesatuan data yang saling mendukung dan melengkapi. Triangulasi data juga dilakukan untuk menggabungkan beberapa subtipe atau semua level data untuk dianalisis. Triangulasi data memberikan keuntungan pada peneliti untuk menangkap berbagai perbedaan dan persamaan data, termasuk di dalamnya dinamisasi data. Metode pengumpulan data pun berjalan secara fleksibel dengan mengedepankan substansi data, kelengkapan, dan konteks data, baik dari sisi waktu, tempat, maupun relasi aktor. Banyaknya informasi, terutama keterhubungan regulasi yang ada, membutuhkan kecermatan dalam melakukan pemilahan dan reduksi data sesuai dengan kebutuhan penelitian.

2) Triangulasi Metode. Triangulasi metode memudahkan peneliti untuk mengumpulkan data, baik dengan wawancara mendalam, penelusuran website, media massa, dokumen perencanaan, maupun observasi. Hasil survei, wawancara, dan observasi dapat dibandingkan untuk melihat adanya kesamaan hasil temuan. Jika kesimpulan dari setiap metode sama, hal itu akan diambil sebagai kesimpulan akhir. Dengan cara ini, peneliti berusaha meningkatkan kepercayaan penelitian, menciptakan cara inovatif dan memahami fenomena, mengungkap temuan unik, menantang atau mengintegrasikan teori, dan memberi pemahaman yang lebih jelas tentang masalah.
3) Triangulasi Teori. Metode ini memudahkan peneliti memilih teori yang sesuai untuk menganalisis data yang diperoleh. Namun, dalam koridor teori jejaring kebijakan, penulis menganalisis data dengan teori aktor dan hubungan aktor Kenis \& Schneider (1991), teori iron triangle, teori identifikasi aktor Dente (2014), teori jejaring aktor Michel Callon (1982), dan teori konfigurasi subsistem Howlett (2002). Penggunaan beragam teori dapat membantu memberikan pemahaman yang lebih baik dan komprehensif saat memahami data. Jika beragam teori menghasilkan kesimpulan analisis yang sama, hal itu diambil sebagai kesimpulan akhir.

\section{Pembahasan}

\section{Aktor dan Jejaring Aktor}

Tahap pertama dan yang esensial dalam pendekatan analisis kebijakan publik, terutama dalam kajian proses pembuatan keputusan, adalah mengidentifikasi para aktor (Dente, 2014). Secara sederhana, aktor sering didefinisikan sebagai subjek yang melakukan suatu perbuatan (act). Definisi ini dalam konteks studi kebijakan publik tentu dapat menyesatkan. Hal ini dapat dilihat dalam konteks seorang pekerja administratif di sebuah lembaga. Dia bekerja keras (act) menyelesaikan aspek-aspek administrasi, tetapi pekerja administratif tersebut tentu saja tidak berpengaruh dalam pengambilan keputusan. Di sisi lain, ada seseorang yang di luar lembaga penentu kebijakan, tetapi dapat berpengaruh atau berpartisipasi terhadap keputusan yang dibuat oleh sebuah lembaga. Orang tersebut, misalnya, adalah penyuap petugas pemerintahan walaupun korupsi secara hukum tentu salah dan dilarang. 
Namun, praktik ini jelas dapat memengaruhi keputusan tindakan penentu kebijakan yang dilakukan oleh orang yang berada di luar sistem pemerintahan.

Aktor dalam kajian ini adalah aktor kolektif, dapat sebagai institusi atau individu. Seorang yang berperan sebagai aktor kolektif harus memiliki preferensi sendiri yang berbeda dengan preferensi tunggal anggotanya. Hal ini menurut Fritz W. Scharpf (Dente, 2014: 32) tergantung pada kondisi berikut.

1. harus ada bentuk kepentingan atau tujuan di tingkat unit utama, yang berarti ada sebuah kondisi untuk keberlangsungan hidup, otonomi, dan pembangunan yang dirumuskan secara jelas;

2. harus sadar dan menghormati aturan formal atau informal jika mereka bertindak atas nama aktor kolektif;

3. harus ada identitas kolektif minimum di setiap entitas ataupun tingkatan yang diketahui para anggota dan ini akan mempermudah penentuan preferensi aktor kolektif dalam membuat keputusan.

Berkaitan dengan tujuan pembangunan WTE sebagai pendorong aktor kolektif seperti yang dimaksud Scharpf dalam angka $1 \mathrm{di}$ atas, sebenarnya telah terdeklarasikan secara bersama-sama dan bukan hanya di unit utama, tetapi di semua level pemangku kepentingan, yaitu bahwa WTE dibangun di satu sisi untuk mengatasi sampah perkotaan dan di sisi yang lain menjawab kebutuhan energi yang terus meningkat. Dengan demikian, syarat terbentuknya aktor kolektif terpenuhi. Sementara itu, untuk identitas kolektif setiap entitas, secara umum dibagi menjadi aktor official policymakers atau pemerintah dan unofficial policymakers atau nonpemerintahan (Popoola, 2016). Gordon Adams (1981) dan F. Gregory Hayden (2002) membagi kelompok nonpemerintah menjadi dua bagian, yakni pemangku kepentingan (swasta/dunia usaha) dan masyarakat atau keterwakilan masyarakat di parlemen. Hubungan antara pemerintah, swasta, dan masyarakat juga dikenal aktor utama dalam teori iron triangle. Popoola, berbeda dengan Adams dan Hayden, berpendapat bahwa masyarakat berbeda dengan parlemen (legislatif) dan meskipun legislatif adalah perwakilan masyarakat, Popoola menempatkannya sebagai bagian dari pemerintahan. Pemisahan oleh Popoola ini relevan dengan sistem pemerintahan di Indonesia, yaitu eksekutif, legislatif, dan yudikatif, yang merupakan satu kesatuan dalam pemerintahan. Jejaring aktor hubungan antara pemerintah, swasta, dan masyarakat dalam pembangunan WTE dapat digambarkan di Bagan 2.

Dalam Bagan 2 terlihat aktor yang masuk dalam kelompok pemerintah adalah pemerintah pusat (presiden dan kementerian), pemerintah provinsi, pemerintah kabupaten atau kota, lembaga peradilan (pengadilan, MA, MK), dan DPR/DPRD. Di pemerintah pusat, selain presiden, ada empat kementerian yang secara teknis langsung berhubungan dengan WTE: Kementerian Energi dan Sumber Daya Mineral, Kementerian Lingkungan Hidup dan Kehutanan, Kementerian Pekerjaan Umum dan Perumahan Rakyat, dan Kementerian Ristekdikti/BPPT. Sementara itu, Kemendagri tidak secara teknis terlibat, tetapi merupakan penanggung jawab penyelenggaraan pemerintahan secara vertikal dari para kepala daerah. Di kelompok swasta, beberapa aktor yang terlibat adalah investor, pengembang dan kontraktor sarana dan prasarana pengolahan sampah, usaha jasa pengolahan sampah atau tempat pembuangan akhir, usaha jasa angkutan/pengumpulan sampah, serta PT PLN sebagai pembeli daya listrik hasil WTE. Sementara itu, aktor di kelompok masyarakat 


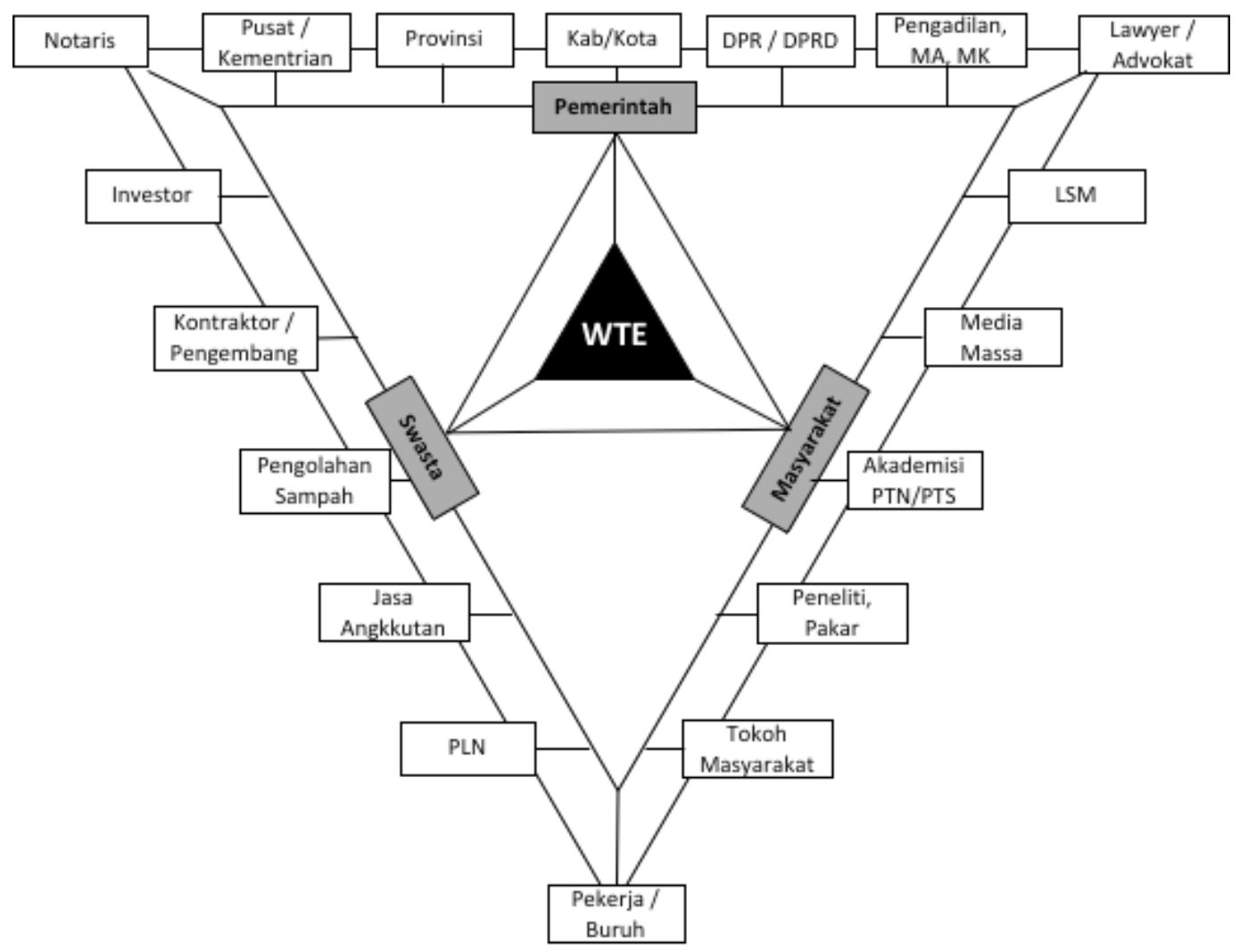

Sumber: Hasil analisis peneliti, 2018

\section{Bagan 2 Jejaring Aktor dalam Pembangunan WTE}

yang memungkinkan terlibat adalah organisasi masyarakat atau LSM, media massa, tokoh masyarakat/adat, akademisi dan perguruan tinggi, serta peneliti independen atau pakar.

Di antara tiga kelompok aktor utama (Pemerintah, swasta, dan masyarakat) tersebut, ada tiga aktor yang menjadi mediasi atau dapat berperan atau menjadi wakil dari dua kelompok aktor yang berada di masingmasing sudut segitiga di Bagan 2. Pertama adalah pekerja/buruh yang dapat menjadi representasi masyarakat sekaligus juga dunia usaha. Kedua adalah penasihat hukum atau advokat yang menjembatani masyarakat dengan pemerintah, terutama jika masyarakat melakukan upaya hukum atas kebijakan yang diambil pemerintah. Ketiga adalah notaris, yang menjembatani kepentingan dunia usaha dengan pemerintah terutama berkaitan dengan aspek legal perusahaan dan perizinan.

Para aktor di atas adalah aktor yang diperankan oleh manusia (human) dengan tujuan dan tugas yang berbeda sesuai dengan tingkat kewenangan dan predikatnya. Selain aktor human, menurut Priyatma (2013), ada aktor non-human dalam jejaring aktor. Teori Jejaring Aktor (TJA) dikembangkan oleh para ilmuwan yang bergerak mempelajari pengembangan sains dan teknologi. Konsep jejaring-aktor pertama digagas oleh Michel Callon di Paris antara tahun 1978 dan 1982 (Law, 2007), juga dikenalkan oleh Bruno Latour dan John Law tahun 1980-an. Menggunakan metafora jejaring aktor, asumsi ontologi yang dipakai oleh TJA adalah realitas (sosial, organisasi, teknologi, dll.) hanyalah hasil atau akibat dari suatu relasi antara 
berbagai jenis entitas, baik yang berupa kebendaan maupun manusiawi (Priyatma, 2013; Law, 1992). Pemikiran Law hingga awal 2000-an masih konsisten, yaitu jejaring aktor terdiri atas human dan non-human, bahkan ia melihat TJA sebagai bagian dari kajian semiotik (Law, 2007).

Sejalan dengan pemikiran Law, Rhodes (2016) mengemukakan bahwa selain pemerintah, ada sesuatu lain yang bukan human yang menjadi kelengkapan pemerintah dalam mengelola jejaring kebijakan. Rhodes menyebutnya dengan istilah metagovernance. Metagovernance adalah sebuah alat yang diciptakan pemerintah yang mengatur aturan main para aktor, hierarki, dialog, identitas para aktor, distribusi sumber daya, dan berperan sebagai pengadil ketika konflik muncul. Rhodes tidak menyebut secara implisit wujud dari metagovernance, tetapi dalam konteks WTE di DKI Jakarta dan tata kelola pemerintahan di Indonesia, metagovernace dapat diartikan sebagai regulasi atau perundang-undangan. Dengan demikian, selain tiga aktor utama dari iron triangle tersebut, ada satu tambahan elemen jejaring kebijakan yang berupa regulasi. Gabungan antara aktor iron triangle (pemerintah, swasta, dan masyarakat) dengan regulasi, penulis sebut sebagai model jejaring kebijakan WTE, yang tergambar sebagai berikut.

Dalam bagan di atas, terdapat kelompok aktor baru berupa regulasi sebagai metagovernance. Sementara itu, Kementerian Energi dan Sumber Daya Mineral (2015) membagi regulasi terkait WTE ke dalam empat kelompok, yakni sektoral, antarsektor, kerja sama pemerintah dengan badan usaha (KPBU), dan pemerintah daerah. Namun, untuk memudahkan pemahaman peraturan tersebut, peneliti pilah menjadi lima kelompok berikut.

1. peraturan pengelolaan sampah. Seperangkat perundangan yang mengatur mengenai manajemen dan pengelolaan sampah adalah UndangUndang No. 18 Tahun 2008 tentang Pengelolaan Sampah; Peraturan Pemerintah No. 81 Tahun 2012 tentang Pengelolaan Sampah Rumah Tangga; Peraturan Pemerintah No. 16 Tahun 2005 tentang Pengembangan Sistem

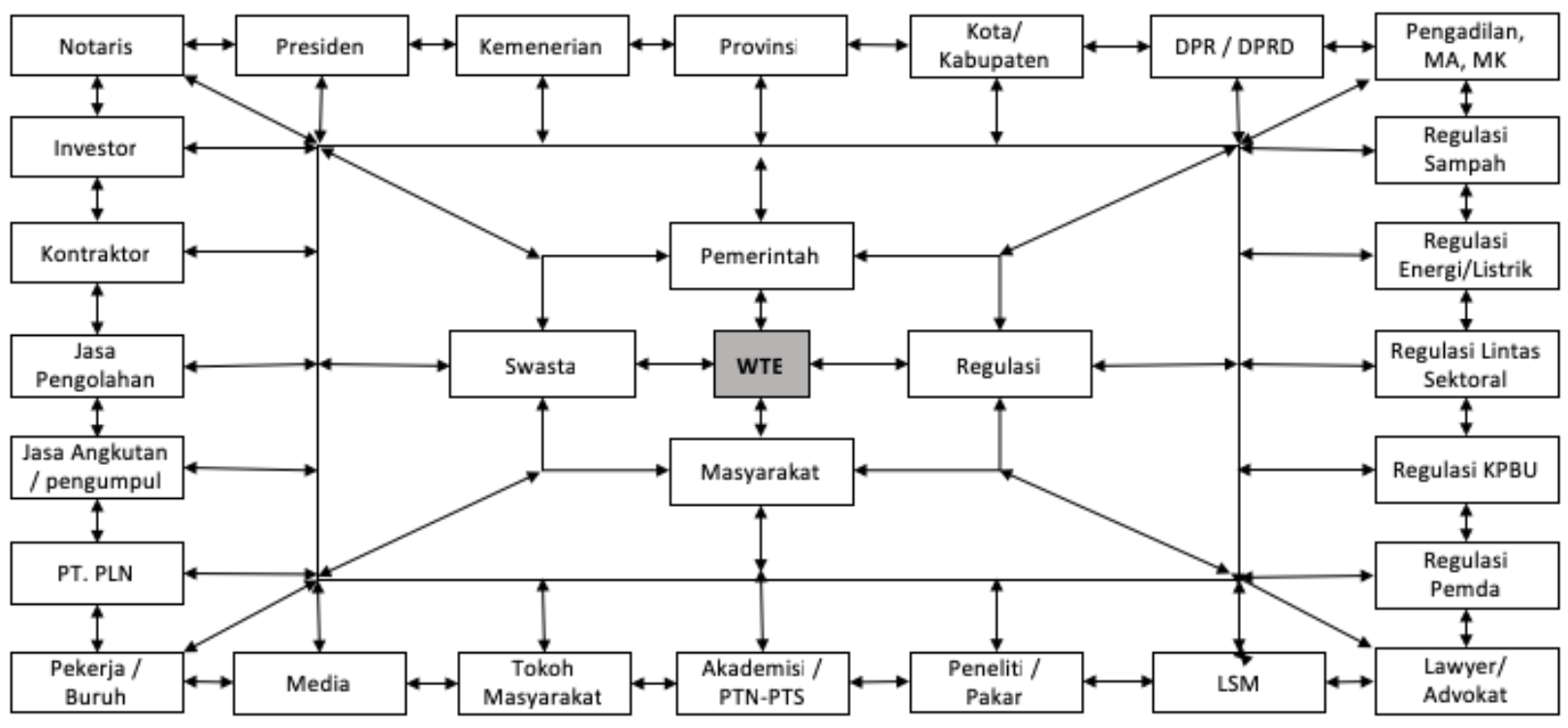


Penyediaan Air Minum; Peraturan Pemerintah No. 50 Tahun 2007 tentang Kerja Sama Daerah; serta Peraturan Menteri Pekerjaan Umum No. 03/PRT /M/2013 tentang Penyelenggaraan Prasarana dan Sarana Persampahan dalam Penanganan Sampah Rumah Tangga dan Sampah Sejenis Sampah Rumah Tangga.

2. peraturan energi dan ketenagalistrikan. Peraturan perundang-undangan di sektor energi dan ketenagalistrikan yang berkaitan dengan pembangunan dan pengelolaan WTE adalah UndangUndang No. 30 Tahun 2007 tentang Energi; UU No. 30 Tahun 2009 tentang Ketenagalistrikan; Peraturan Pemerintah No. 14 Tahun 2012 tentang Kegiatan Usaha Penyediaan Tenaga Listrik; Peraturan Menteri ESDM No. 44 Tahun 2015 tentang Pembelian Tenaga Listrik oleh PT PLN dari Pembangkit Listrik Berbasis Sampah Kota dan Peraturan; Peraturan Menteri ESDM No. 12 Tahun 2017 tentang Pemanfaatan Sumber Energi Baru Terbarukan untuk Penyediaan Tenaga Listrik.

3. peraturanlintas sektoral. Kementerian ESDM (2015) menjelaskan bahwa peraturan antarsektor terkait dengan pendirian WTE adalah yang berkaitan dengan pengadaan tanah, pendirian Perusahaan Pelaksana Proyek atau Special Purpose Company (SPC), investasi, kompetisi usaha, keselamatan kerja, konstruksi, dan lingkungan hidup.

4. peraturan Kerja sama Pemerintah dengan Badan Usaha (KPBU). Istilah KPBU merupakan terminologi yang berasal dari Peraturan Presiden No. 38 Tahun 2015 tentang Kerja Sama Antara Pemerintah dan Badan Usaha dalam

\begin{abstract}
Penyediaan Infrastruktur. Peraturan lainnya yang berkaitan dengan kerja sama antara pemerintah dan badan usaha juga diatur dalam Peraturan Pemerintah No. 27 Tahun 2014 tentang PengelolaanAset Negara/Daerah, yang sebelumnya dikenal dengan Peraturan Pemerintah No. 6 Tahun 2006 tentang Pengelolaan Aset Negara/Daerah; dan Peraturan Pemerintah No. 50 Tahun 2007 tentang Kerja Sama Daerah.
\end{abstract}

5. peraturan pemerintah daerah (provinsi dan/atau kotamadya/ kabupaten). Berdasarkan UU No. 18 Tahun 2008, pemerintah daerah provinsi atau kabupaten/kota wajib menetapkan peraturan daerahnya masing-masing untuk mengatur kegiatan pengelolaan sampah. Peraturan daerah ini harus mengatur persyaratan/persetujuan pemberian izin dari kepala daerah yang terlibat dalam pengelolaan sampah. Selain itu, pemerintah daerah juga harus mempersiapkan dan mengalokasikan anggaran untuk membiayai kegiatan pengelolaan sampah (ESDM, 2015).

Dalam konteks pengolahan sampah menjadi energi listrik di Provinsi DKI Jakarta, model jejaring semua aktor tersebut perlu didefinitifkan sesuai dengan aktor yang sedang berperan. Selain mengungkapkan dan menginventarisasi para aktor, dalam analisis teori jejaring kebijakan yang dikemukakan Kenis dan Schneider (1991), tahap berikutnya adalah menjelaskan hubungan antaraktor dan batasan kewenangan (boundary) antaraktor di dalam jejaring tersebut. Berikut adalah para aktor yang secara definitif terlibat dalam pengelolaan sampah di Provinsi DKI Jakarta beserta dengan pola hubungan dan batas kewenangannya. 
Tabel 1 Hubungan dan Kewenangan Aktor

\begin{tabular}{|c|c|c|}
\hline AKTOR & $\begin{array}{l}\text { HUBUNGAN AKTOR } \\
\text { DENGAN PROV DKI }\end{array}$ & KEWENANGAN \\
\hline $\begin{array}{l}\text { PEMERINTAH } \\
\text { - Kemen PUPR } \\
\text { - Kemen LHK } \\
\text { - Kemen ESDM } \\
\text { - } \text { BPPT / } \\
\text { Kemenristekdikti } \\
\text { - Prov DKI Jakarta } \\
\text { - Prov Jabar } \\
\text { - Kota Bekasi }\end{array}$ & $\begin{array}{l}\text { - Hierarkis } \\
\text { - Hierarkis } \\
\text { - Hierarkis } \\
\text { - Hierarkis } \\
\text { - } \text { Pengelola } \\
\text { - Kemitraan } \\
\text { - Kemitraan }\end{array}$ & $\begin{array}{l}\text { - Aspek sarana pengolahan sampah } \\
\text { - Aspek lingkungan } \\
\text { - } \text { Aspek energi listrik } \\
\text { - } \quad \text { Penanggung jawab pengelolaan } \\
\text { - Izin lahan TPST Bantargebang } \\
\text { - Izin lahan TPST Bantargebang }\end{array}$ \\
\hline $\begin{array}{l}\text { SWASTA } \\
\text { - Jasa angkutan } \\
\text { - PT PLN } \\
\text { - PT Jakpro } \\
\text { - PT Godang Tua } \\
\text { Jaya } \\
\text { - PT Navigat Organic } \\
\text { Energy Indonesia }\end{array}$ & $\begin{array}{l}\text { - Kemitraan } \\
\text { - Kemitraan } \\
\text { - Kemitraan } \\
\text { - Kemitraan } \\
\text { - Kemitraan }\end{array}$ & $\begin{array}{l}\text { - Pengelola angkutan sampah } \\
\text { - Pembeli listrik } \\
\text { - Pengembang dan pengelola ITF } \\
\text { Sunter } \\
\text { - Kontrak kerja sama pengelola TPST } \\
\text { Bantargebang diputus sejak Juli } 2016 \\
\text { - Kontrak kerja sama pengelola TPST } \\
\text { Bantargebang diputus sejak Juli } 2016\end{array}$ \\
\hline $\begin{array}{l}\text { MASYARAKAT } \\
\text { - LSM } \\
\text { - Media } \\
\text { - Akademisi/ PT } \\
\text { - Peneliti Independen }\end{array}$ & $\begin{array}{l}\text { - Kemitraan } \\
\text { - Kemitraan } \\
\text { - Kemitraan } \\
\text { - Kemitraan }\end{array}$ & $\begin{array}{l}\text { - Fungsi kontrol, kerja sama } \\
\text { pemberdayaan } \\
\text { - } \text { Fungsi kontrol, kerja sama publikasi } \\
\text { - Kajian akademis kebijakan dan } \\
\text { perencanaan } \\
\text { - Kajian ilmiah kebijakan dan } \\
\text { perencanaan }\end{array}$ \\
\hline
\end{tabular}

Sumber: Hasil analisis peneliti, 2018

Pada 2011 Pemprov DKI Jakarta mengoperasikan WTE berbasis landfill gas to energy di TPST Bantargebang. Pengoperasiolan itu merupakan hasil kerja sama dengan PT Navigat Organic Energy Indonesia (PT NOEI) dan PT Godang Tua Jaya (PT GTJ). PT NOEI bertanggung jawab pada proses pengolahan gas menjadi energi, sedangkan PT GTJ bertugas pada pengelolaan landfill untuk kebutuhan penyaringan gas. PT GTJ juga bertanggung jawab pada pengelolaan sampah secara umum di TPST Bantargebang. Selanjutnya pada Juli 2016 Pemprov DKI Jakarta memutus kerja sama dengan dua perusahaan tersebut dan mengambil alih seluruh pengelolaan secara swakelola.

Pada Mei 2018 Pemprov DKI memulai pembangunan pengolahan sampah menjadi energi ITF Sunter yang rencananya berbasis teknologi insenerator. Pembangunan ini bekerja sama dengan PT Jakpro sebagai pengembang dan pengelola. Pada saat yang bersamaan juga Pemprov DKI membangun pengolahan yang sama dalam skala yang lebih kecil di TPST Bantargebang. Pembangunan ini bekerja sama dengan BPPT dan PT Jakpro untuk kepentingan penelitian atau prototype design bagi ITF Sunter. 
Konfigurasi Subsistem

Dari pemetaan aktor dan pola jejaring di atas, dapat dilihat bahwa tipologi jejaring kebijakan dalam WTE lebih bertumpu pada hubungan pemerintahan. Hampir semua jejaring menjadikan pemerintah, terutama Pemprov DKI Jakarta, sebagai simpul jejaring dan elemen regulasi sebagai metagovernance. Tipologi jejaring seperti ini disebut Howlett dan Rayner (1995) sebagai jejaring bertipe birokratik. Jika yang dominan adalah masyarakat, tipe jejaringnya adalah partisipatori. Howlett dan Rayner (1995) mengklasifikasikan tipe birokratik ke dalam tiga tipe: clientelistic (partisipan terdiri atas satu grup utama), triadic (partisipan terdiri atas dua grup utama), dan pluralistic (partisipan terdiri atas tiga grup utama atau lebih). Jika melihat koalisi advokasi yang terbentuk pada subsistem di subbab sebelumnya, tipe jejaring kebijakan yang terbentuk di WTE di Provinsi DKI Jakarta adalah birokratik-pluralistik.

Kinerja jejaring bertipe birokratikpluralistik tersebut dapat diukur dengan mengawinkan atau melakukan tabulasi silang antarbeberapa variabel. Oleh Howlett (2002), tabulasi silang tersebut dibagi dalam dua kelompok operasionalisasi. Pertama adalah operasionalisasi perubahan kebijakan (Operationalizing Policy Change) dan kedua adalah operasionalisasi kebijakan subsistem

Tabel 2 Operasionalisasi Perubahan Kebijakan

a. A Basic Taxonomy of Policy Change by Mode and Speed of Change

\begin{tabular}{|c|c|c|}
\hline \multirow{2}{*}{ Mode of Change } & \multicolumn{2}{|c|}{ Speed of Change } \\
\hline & Fast & Slow \\
\hline Paradigmatic & Rapid Paradigmatic & Gradual Paradigmatic \\
\hline Normal & Rapid Incremental & Gradual Incremental \\
\hline \multicolumn{3}{|c|}{ b. An Operationalized Model of Policy Change } \\
\hline \multirow{2}{*}{ Entrance of new ideas } & \multicolumn{2}{|c|}{ Entrance of new actors } \\
\hline & Yes & No \\
\hline Yes & Policy Goals & Programme Specifications \\
\hline No & Policy Instrument types & Instrument Components \\
\hline
\end{tabular}

Sumber: Howlett, 2002

Tabel 3 Operasionalisasi Kebijakan Subsistem

a. Basic Policy Subsystem Configurations

\begin{tabular}{lll}
\hline \multirow{2}{*}{ Receptive to new ideas } & \multicolumn{2}{c}{ Receptive to new actors } \\
\cline { 2 - 3 } & \multicolumn{1}{c}{ No } & \multicolumn{1}{c}{ Yes } \\
No & Closed Subsystem & Resistant Subsystem \\
Yes & Contested Subsystem & Open Subsystem \\
\hline
\end{tabular}

b. Preliminary Operationalizing of Policy Subsystem Configurations

\begin{tabular}{lll}
\multicolumn{2}{c}{ Extent of symmetry between } & \multicolumn{2}{c}{ Network's degree of insulation from community } \\
\cline { 2 - 3 } \multicolumn{1}{c}{ community and network } & \multicolumn{1}{c}{ High } & \multicolumn{1}{c}{ Low } \\
\hline High & Closed Subsystem & Resistant Subsystem \\
Low & Contested Subsystem & Open Subsystem \\
\hline
\end{tabular}

Sumber: Howlett, 2002 
(Operationalizing Policy Subsystems). Selanjutnya berikut ini adalah tabulasi silang (crosstab) variabel dalam operasionalisasi perubahan kebijakan dan kebijakan di dalam subsistem.

Menganalisis model operasional perubahan kebijakan dimulai dengan pengamatan bahwa sebagian besar kebijakan yang dibuat oleh pemerintah, dalam beberapa cara merupakan kelanjutan dari kebijakan dan praktik masa lalu. Sesuatu yang sering digambarkan sebagai inisiatif kebijakan 'baru', bahkan sering kali hanya merupakan variasi pada praktik-praktik yang ada. Hal itu berarti bahwa dalam keadaan normal, masalah atau masalah kebijakan akan ditangani dengan mengacu pada praktik yang ada, atau seperti yang digambarkan di Tabel 2a di atas sebagai mode marginal atau inkremental. Pola perubahan kebijakan yang sedikit demi sedikit ini adalah pembuatan kebijakan yang 'normal'. Demikian pula, perubahan kebijakan berikutnya (dalam Tabel 2a) adalah pola yang sering melibatkan rekonseptualisasi dan penataan ulang kebijakan yang lebih dramatis. Jenis perubahan kebijakan ini biasanya digambarkan dalam literatur sebagai 'paradigmatik'. Secara keseluruhan, perubahan paradigmatik melibatkan periode stabilitas dan adaptasi tambahan diselingi oleh periode pergolakan revolusioner serta menghasilkan yang sering disebut sebagai punctuated equilibrium dalam dinamika kebijakan (Howlett, 2002).

Sementara itu, perubahan kebijakan yang dilakukan Pemprov DKI Jakarta dalam rangka pengelolaan sampah terjadi secara paradigmatik, dari paradigma konvensional yang memosisikan landfill sebagai pengolahan utama menuju paradigma baru dengan landfill sebagai pemrosesan akhir atau sisa dari pengolahan lainnya (reuse, reduce, recycle atau disebut $3 \mathrm{R}$ ) dan pengolahan menjadi energi. Namun, jika melihat Rencana Induk Sistem Pengelolaan Sampah (RISPS) yang dbuat sejak 2011, pelaksanaan perubahan itu tentu berjalan secara lambat (gradual). Dengan demikian, jika mengacu pada tabel pertama Howlett (2002), model perubahan kebijakan pengelolaan sampah di Provinsi DKI Jakarta ini berjalan secara gradualparadigmatik.

Model gradual-paradigmatik tersebut dioperasikan oleh Pemprov DKI Jakarta dengan cara bertumpu pada tujuan-tujuan kebijakan (policy goals). Dalam Tabel 2b dari Howlett di atas dijelaskan tentang variabel operasionalisasi perubahan kebijakan, yang merupakan kemunculan atau masuknya ide baru dan aktor baru dalam pengelolaan sampah menjadi energi. Pemprov DKI terbuka dengan hadirnya ide baru dengan membuat revisi master plan secara berkala sesuai dengan perkembangan ilmu pengetahun dan teknologi, termasuk juga dengan bekerja sama dengan BPPT sebagai wujud mengakomodasi ide kebutuhan terhadap green technology.

Di saat yang bersamaan Pemprov DKI juga terbuka dengan kehadiran aktor-aktor baru dalam pengelolaan sampah menjadi energi, di antaranya adalah bekerja sama dengan BPPT dan PT Jakpro. Pemprov DKI, bahkan berencana merangkul LSM untuk bekerja sama. "Ke depan secara masif akan dilakukan sosialisasi kepada masyarakat dibantu juga oleh pihak konsultan dan LSM," menurut Kepala Dinas Lingkungan Hidup Provinsi DKI Jakarta, Isnawa Adji, dalam wawancara pada 16 November 2018. Dua indikator variabel (kecepatan perubahan dan model perubahan, seperti pada Tabel 2) menunjukkan bahwa perubahan kebijakan yang terjadi berorientasi pada tujuan-tujuan kebijakan (policy goals). Dengan demikian, perubahan kebijakannya berjalan secara gradual-paradigmatik dengan berorientasi pada tujuan kebijakan. 
Tahap berikutnya adalah mengukur konfigurasi yang terjadi di subsistem. Sehubungan dengan pengembangan uji pengaruh subsistem kebijakan terhadap perubahan kebijakan, dimungkinkan adanya penggunaan model yang relatif sederhana yang menghubungkan jenis subsistem dasar dengan dua variabel utama yang dianggap berada di belakang dinamika kebijakan fundamental: ada atau tidaknya ide-ide baru dan aktor-aktor baru dalam pembahasan kebijakan (Howlett, 2002). Dalam Tabel 3 dari Howlett tentang konfigurasi dasar kebijakan subsistem, terlihat tabulasi silang antara variabel ide baru dengan aktor baru. Dalam konteks subsistem di pembangunan WTE Provinsi DKI Jakarta, kedua variabel itu dinyatakan terbuka (ya/yes) terhadap ide dan aktor baru sehingga subsistem yang terkonfigurasi adalah open subsystem (subsistem terbuka).

Berikutnya adalah mengukur operasionalisasi di dalam konfigurasi subsistem. Ada dua dimensi penting dari struktur subsistem dan isu jaringan. Pertama adalah dalam arti yang absolut, yaitu potensi aktor baru untuk berpindah dari komunitas ke jaringan bergantung pada tingkat simetri, atau tingkat tumpang-tindih antara jaringan dan komunitas yang ada di subsistem. Kedua, terlepas dari ukuran keseluruhan subsistem dan komponennya, sejauh mana jaringan kepentingan terisolasi dari komunitas diskusinya. Hal itu terkait dengan sejauh mana ide-ide baru dapat bergerak di antara masyarakat dan jaringan atau, dalam hal ini, antara dunia kebijakan dan masyarakat (Howlett, 2002). Baik dari sisi kesimetrian jaringan maupun tingkat isolasi komunitas, di dalam perubahan kebijakan pengelolaan sampah di Provinsi DKI Jakarta, keduanya tergolong dalam tingkat yang rendah (low). Dengan demikian, operasionalisasi konfigurasi kebijakan dalam subsistem termasuk dalam kategori open subsystem.

\section{Kesimpulan}

Dari empat tabel variabel (Tabel 2a, 2b, 3a, dan 3b) perubahan kebijakan dan konfigurasi subsistem, dapat disimpulkan bahwa pembangunan WTE di Provinsi DKI Jakarta berjalan di atas subsistem yang terbuka dalam menjalankan perubahan paradigma secara gradual dan berorientasi pada tujuan kebijakan. Dengan jejaring aktor dan konfigurasi subsistem yang seperti itu, sebenarnya percepatan pembangunan WTE di Provinsi DKI Jakarta terbuka lebar. Percepatan dapat dilakukan, misalnya dengan memperbesar jejaring aktor, memobilisasi elemen/aktor lain di luar jaringan untuk bergabung di dalam jejaring kebijakan, dan/atau aktor penghambat diakuisisi menjadi aktor pendukung. Sebagai contoh, mobilisasi aktor yang dapat dilakukan oleh Pemprov DKI Jakarta dan BPPT adalah dengan merangkul perguruan tinggi dalam penelitian dan pengembangan teknologi sehingga tercipta kerja sama tripple helix. Sementara itu, contoh penggalangan aktor adalah dengan merangkul masyarakat dan LSM untuk berperan aktif dalam proses dan operasionalisasi WTE sesuai dengan keahliannya.

\section{Daftar Pustaka}

Adams, Gordon. 1981. The Iron Triangle: The Politics of Defense Contracting. New York, Council on Economic Priorities.

Bappenas. 2010. Indonesia Climate Change Sectoral Roadmap (ICCSR) 2010. Jakarta, Bappenas.

----. 2017. Public Private Partnerships. Jakarta, Bappenas. 
BPS. 2016. Statistik Indonesia 2016. Jakarta, Badan Pusat Statistik Republik Indonesia. -----. 2017. Laporan Bulanan Data Sosial Ekonomi Juni 2017. Jakarta, Badan Pusat Statistik Republik Indonesia, Edisi 85.

Dente. 2014. "Who Decides? Actors and Their Resources", Understanding Policy Decisions. PoliMI SpringerBriefs.

Hayden, Gregory. 2002. "Policymaking Network of the Iron-Triangle Subgovernment for Licensing Hazardous Waste Facilities", Journal of Economic Issues, CBA Faculty Publications. Lincoln, University of Nebraska.

Howlett \& Rayner. 1995. "DO ideas matter? Policy network configurations and resistance to policy change in the Canadian forest sector", Canadian public administration.

Howlett, Michael. 2002. "Do Networks Matter? Linking Policy Network Structure to Policy Outcomes: Evidence from Four Canadian Policy Sectors 1990-2000", Canadian Journal of Political Science. Burnaby.

Howlett, Michael and Ramesh, M. 1995. Studying Public Policy: Policy Cycles and Policy Subsystems. Oxford University Press. Kenis \& Schneider. 1991. "Policy networks and policy analysis: Scrutinizing a new analytical toolbox", Policy networks: Empirical evidence and theoretical considerations (pp. 25-59), Boulder, Colorado: Westview Press.

Kompas. 2018. "ITF Sunter Akan Ubah 2.200 Ton Sampah Per Hari Jadi 35 Megawatt". Jakarta.

Law, J. 1992. Notes on the theory of the actor-network: Ordering, strategy, and heterogeneity. Systems Practice.

-----. 2007. "Actor network theory and material semiotics", http://www. heterogeneities.net/publications/ LawANTandMaterialSemiotics.pdf.
Popoola, Olufemi O. 2016. "Actors in Decision Making and Policy Process", G.J.I.S.S., Vol. 5(1): 47-51, Global institute for research and education.

Priyatma, Johanes Eka. 2013. Potensi Teori Jejaring Aktor Untuk Memahami Inovasi Teknologi. Yogyakarta, Seminar RiTekTra.

Rhodes. 2016. The Theory and Practice of Governance: the Next Steps. Wuhan University.

Shull, Steven A. 1999, American Civil Rights Policy from Truman to Clinton: The Role of Presidential Leadership/ York and London, M.E Sharpe, Armonk New. 